\title{
Substantiation of the Priorities and Factors of the Formation of Competitive Advantages of the Process Industries of the Regional Agroindustrial Complex
}

\section{Sustanciación de las prioridades y factores de la formación de ventajas competitivas de las industrias de procesos del complejo agroindustrial regional.}

\author{
Safarbi M. Pshikhachev ${ }^{1}$, Fatima Y. Karayeva ${ }^{2}$, Nikolay S. Kokov', \\ Rameta Y. Shokumova', Musa A. Eskiev ${ }^{3}$ \\ ${ }^{1}$ Candidate of Economics, Associate Professor at Kabardino-Balkarian State \\ Agrarian University named after V.M. Kokov \\ 2 Doctor of Economics, Associate Professor at Kabardino-Balkarian State \\ Agrarian University named after V.M. Kokov \\ ${ }^{3}$ the lecturer at Chechen State University
}

Enviado: 27 de junio de 2019

Aceptado para publicar: 30 de julio de 2019

Publicado: 8 de agosto de 2019

\begin{abstract}
Among the many distinctive features of the modern technical and economic situation of the reclamation industry, such as financial volatility, inconsistency of regulatory documents, there is also no effective mechanism for ensuring the country's food security, there are flaws in the organizational, financial and credit policy, which brought down the technical level of production and technological processes ...

In view of this, there is a need to mainstream a detailed study of the key problems of the agroindustrial complex (AIC) and the development of new theoretical and methodological principles and approaches to the organization of agroindustrial production. Such an approach should ensure the development of modern systems of resource-saving technologies, which will make it possible to carry out timely and deep processing of agri supplies, advance the facilities for attracting investments in priority production and agroprocessing, improve the quality and competitiveness of food and process industries, etc.

The protracted transition in the agrarian sector to market relations can be explained by a narrow understanding of the essence of the market economy, measures and methods of their state regulation, which led to undesirable tendencies, ignoring national-historical features in the agrarian sector, etc., which makes it necessary to find an appropriate economic mechanism capable of guaranteeing the production of competitive products and ensuring high quality of production.

On account of insufficient elaboration of many theoretical and methodological, methodical and practical aspects, the need for further research in the field of forecasting the sustainable development of the processing industry, complexity and non-systemic knowledge of the competitive functioning of the processing industries of the agroindustrial complex, we have determined its purpose and objectives.
\end{abstract}

Keywords: market economy, economic crisis, food security, agroindustrial complex, processing industry, competitive advantages, sustainable development.

Entre las muchas características distintivas de la moderna situación técnica y económica de la industria de la recuperación, como la volatilidad financiera, la inconsistencia de los documentos reglamentarios, tampoco existe un mecanismo efectivo para garantizar la seguridad alimentaria del país, existen fallas en la organización, las finanzas y el crédito. política, que redujo el nivel técnico de producción y los procesos tecnológicos ...

En vista de esto, es necesario incorporar un estudio detallado de los problemas clave del complejo agroindustrial (AIC) y el desarrollo de nuevos principios y enfoques teóricos y metodológicos para la organización de la producción agroindustrial. Tal enfoque debería garantizar el desarrollo de sistemas modernos de tecnologías de ahorro de recursos, que permitirán llevar a cabo un procesamiento oportuno y profundo de los suministros agrícolas, avanzar en las instalaciones para atraer inversiones en producción prioritaria y agroprocesamiento, mejorar la calidad y competitividad de industrias de alimentos y procesos, etc.

La transición prolongada en el sector agrario a las relaciones de mercado puede explicarse por una comprensión limitada de la esencia de la economía de mercado, las medidas y los métodos de su regulación estatal, lo que condujo a tendencias indeseables, ignorando las características históricas nacionales en el sector agrario, etc. ., lo que hace que sea necesario encontrar un mecanismo económico apropiado capaz de garantizar la producción de productos competitivos y garantizar una alta calidad de producción.

Debido a la insuficiente elaboración de muchos aspectos teóricos y metodológicos, metodológicos y prácticos, la necesidad de una mayor investigación en el campo de previsión del desarrollo sostenible de la industria de procesamiento, la complejidad y el conocimiento no sistémico del funcionamiento competitivo de las industrias de procesamiento de complejo agroindustrial, hemos determinado su finalidad y objetivos.

Palabras clave: economía de mercado, crisis económica, seguridad alimentaria, complejo agroindustrial, industria procesadora, ventajas competitivas, desarrollo sostenible. 


\section{Introduction}

The agroindustrial complex of the Russian Federation is today one of the largest industrial complexes of the national economy. The socioeconomic and material welfare of its population depends on the level of sustainability of the agrarian environment of the country.

It should be noted that the agrarian and industrial complex of the Russian Federation accounts for almost a third of the gross social product, a quarter of the basic production assets and about a third of the number of workers employed in the material sphere of production. Moreover, agroindustrial products account for almost $80 \%$ of retail sales. It can be briefly noted that the political and socio-economic situation in the country and the sustainability of its development depend on the state of affairs in the agroindustrial complex on the whole $[1,10]$.

The formation and development of the agroindustrial complex was determined by the continuously developing process of the social division of labor, the deepening of specialization. All this was accompanied by the need for higher forms of inter-sectoral cooperation, integration, the formation of federal and regional, as well as inter-branch components as the objects of management.

In recent years, a lot of scientific discussions concerning uninterrupted, affordable and highquality food supply to the population, analysis of changes in the dynamics of demographic processes, and socio-economic tensions have been taking place in our country.

During these discussions, there is no dispute over the fact that one of the key roles in solving this complex problem belongs to the state of affairs in the processing industry in the agroindustrial complex.

It is noteworthy that processing has not left agriculture in no country (even the most developed), although the historical process of its development during all the years of its existence indicates the presence of a certain regularity, "objective extrusion" of processing from the agricultural sector into the industry. Moreover, the process of continuous development of the processing industry led it to territorial shifts, as a result of which it became even closer to the territories where the production of primary agricultural products is located, accompanied by integration processes, cooperation, etc

\section{Research Methods}

Depending on the subject of the problems and tasks under consideration, in the course of the study we applied various general research methods and techniques, including systematic approach, general scientific methodology involving methods of predictive, comparative, statistical, factor analyses, logical generalization. The information base of the research was the works of Russian and foreign scientists in the field of agroindustrial production management, FSSS data on the Russian Federation, etc.

\section{Research Results}

The peculiarity of the processing industry is that it acts as an integral, and at the same time, relatively separate part of the agroindustrial complex, and the problems of its sustainability and competitive growth are directly connected with the general socio-economic situation of the country.

At the initial stage of the formation of market relations in our country (1991-1995), a company to combat monopolism through the disaggregation of the enterprises of AIC was conducted.

A course was taken for the development of small business and small enterprises. It was expected that small enterprises (unlike monopolistic giants) would be able to respond more quickly to the changes in demand, to various seasonal variations in agroindustrial production.

But in fact, it turned out to be the opposite - small enterprises of the agroindustrial complex were technically outdated, they practically did not use secondary raw materials, etc. $[2,11]$.

It should be noted that the privatization of enterprises in the agroindustrial complex only aggravated the socio-economic problems accumulated over the previous years. This was expressed in the falling of production volumes, the rising of costs, the falling of investment, lower incomes and living standards of workers, social facilities were almost completely lost...

Most of the processing enterprises of the agroindustrial complex used the second model of privatization, as a result of which the team had a significant part of the shares, allowing them to control the enterprise. This was profited by large monopolistic enterprises, which, in the course of unscrupulous economic policy, managed to make their suppliers of agricultural resources being completely dependent on them ...

In recent years, some kind of stabilization and positive dynamics on a range of significant indicators of the country's socio-economic development have appeared in agroindustrial complex, but at the same time, it is faced with the signs of growth extinction in the sphere of material production, the general economic situation is deteriorating and the proportion of unprofitable enterprises is still very high. This has resulted in declining the production of agroindustrial products almost by half, in agriculture - by $40 \%$ during the period of formation of market relations in the Russian 
Federation, which limits the country's ability to supply the population with its own production.

It seems to us that the reasons for this situation lie in the unregulated market relations, the growth in the inequality of industrial and agricultural products, the accelerated massive privatization, carried out without taking into account the sectoral and territorial specifics of the national economy, breaking the current system of economic management without developing its new forms that that are in keeping with the reforms being implemented in market economy $[2,14]$.

As a result, the processing enterprises of the agroindustrial complex were forced to work in the mode of raw material shortages, which immediately began to negatively affect the level of nutrition with basic foodstuffs in terms of energy value and the structure of the region.

For example, everyday use of vegetable fats in the production of many types of products became commonplace for Russians. At present, the average daily energy nutrition of a Russian is 2550 kcal, while FAO recommends consuming at least $3000 \mathrm{kcal}$. According to this indicator, Russia ranks 50th in the world.

The researchers note that the demand for ordinary dairy products (kefir, milk, curds) is inelastic in price. At the same time, with the growth of citizens' incomes, the demand for more expensive dairy products (cheeses, complex cocktails, yogurts, etc.) also increases.

The growth of demand for dairy products mobilizes the development of production, sets up dairy plants to increase the volume of dairy products and expand the range.

And today at food industries there is an unacceptable depreciation of fixed production assets. Thus, the requirements of economic entities of the food industry of the KabardinoBalkaria Republic (supplying up to $20 \%$ of all canned products in the south of the country) are only $40-45 \%$ satisfied in refrigeration, process and energy equipment.

Most of the process equipment required for the industry is not produced at all in the Russian Federation, and only $20 \%$ from what is being produced corresponds to world standards.

At the same time, about $40 \%$ of the equipment is to be immediately changed, and $20 \%$ - to be updated. And such lagging will have been at least for 30 years, because the annual production assets are updated within 3-4\%, which is at least 2 times less than the average world values of advanced countries.

In light of this, it is advisable to think back to the experience of MTS with consideration to the involvement of foreign capital and leasing. It is also necessary to develop and implement a program for the production of agricultural equipment at enterprises, which will make it possible to achieve a significant economic effect using cost effective technologies and create a new innovative material.

All this is undoubtedly in keeping with the national interests of ensuring its economic resilience.

Agroindustrial enterprises have much difficulty in crediting food and processing enterprises of the agroindustrial complex. The global economic crisis has aggravated the industrial enterprises' difficulties, which requires the urgent conditioning for the stabilization of the financial and production activities of enterprises [5,12,9].

In addition, it is necessary to introduce and regularly monitor the financial, economic and technological status of economic entities of the agroindustrial complex, control the timeliness of salary payments to employees in the industry, monitor enterprises that are at bankruptcy risk. However, it must be admitted that the profit is purely nominal in many enterprises of the agroindustrial complex, as a result of which their financial position is an adversely significant deterrent to the formation of competitive advantages and economic growth. Of the 59 processing enterprises of the Kabardino-Balkaria Republic, only 7 have high-production environment and apply advanced technologies $[3,4,11]$.

It should be noted that in a depressed republic where there is no investment attractiveness, although $16 \%$ of enterprises are developing quite successfully, $84 \%$ of enterprises drag on a wretched existence. Apparently, this circumstance explains the fact that the regional food market of the republic has shifted to foreign and Russian entrepreneurs from other regions with good reason.

There are also major changes in the structure of process costs for foodstuff manufacturing. The industry we are considering is one of the most material-intensive branches of the agroindustrial sector, it is characterized by a high proportion of the cost of raw products and materials - they account for $72 \%$ today (for comparison, it was $65 \%$ in 2010).

Obviously, the reduction of the materials consumption of agroindustrial products should be carried out without deterioration (and sometimes with improvement) of product quality. Industrialists point out that recently the agricultural raw materials supplied to agricultural enterprises have not met the changes either in terms of volume or quality, which prevents their rational use.

Absolutely a green-field problem is the problem of integrated use of raw materials and waste reclamation. Secondary raw materials are created in the AIC system at the processing enterprises of meat and dairy, oil and fat, sugar, fruit and vegetable and other industries. At the same time, 
up to $60-90 \%$ of the mass of initial material with a number of derived costs in the form of costs for wages, deductions for its needs, etc. go to waste. It should be noted that labor costs and related allocations over the past 6 years have decreased and in 2018 they did not exceed $10.5 \%$ and $2.5 \%$, respectively.

At all levels of state structures, for several decades they have been talking about disparity in prices for engineering products, agricultural products and products of the processing sub-complex of the $\mathrm{AIC}$, but, as the saying goes, "things are right where they started". Although it is well known that in such a situation it is never possible to carry out a complete renovation and modernization of fixed assets, reconstruction on an extended basis. It is difficult to comment on this, especially given the fact that more than $45 \%$ of run-down equipment has been in operation for more than 10 years $[7,8,13]$.

This situation (acute shortage of modern technological equipment) brings significant losses in the profitability of agroindustrial products and resources. There are already a lot of implemented scientific developments for the advanced processing of agri supplies that allow rational and highly profitable use of agricultural resources, but, unfortunately, they are practically not used in the depressed agriculturally oriented republics of the North Caucasus Federal District due to lack of financial resources, due to their high capital intensity.

Labor productivity or output, consumption of equivalent fuel, in Russian enterprises, for example, sugar from beets are beyond the comparison with factories in France, Germany, etc.

There are calculations that suggest that obtaining $\%$ of the increment in food products due to advanced processing, loss reduction, rational use of processed raw materials is 3-4 times cheaper than with ordinary technologies.

But the so-called monopolistic enterprises are not doing so well - due to the lack of necessary funds and proper state support, they are forced to take agri supplies for toll processing - especially sugar beet (up to 90\%) and sunflower seeds (up to $70 \%$ ).

Moreover, this is not happening directly, but through intermediaries, who, by the way, themselves buy from agricultural producers at dumping prices. Characteristically, with such approach, most of the profits go to intermediary organizations, while the interests of agricultural producers and processors are completely ignored. The main factors for strengthening competitive positions in a market economy are, first of all, the quality of raw materials. Tellingly, in the Soviet period quantitative indicators were of great importance, quality indicators were in the background. The manufacturer was practically not in contact with consumers, moreover, if he had to choose from two directions - either to leave the same costs and the same quality or to increase costs for improving the quality - he chose the first.

But this is absolutely impossible with market relations. In the Russian Federation, up to $30 \%$ of canned meat, alcoholic beverages, sausages are rejected as defective every year ... This situation is explained by many factors, including lack of market thinking, low economic culture, etc.

Another problem is the total dependence of industrial enterprises on the services of natural monopolists, constantly and unilaterally raising tariffs for energy, utilities, transport, etc. All this is accompanied by a rather high inflation.

The problem of the safety of foods derived from genetically modified microorganisms is a separate subject. Year in year out, the production of such products has been steadily growing all over the world, especially in industrially advanced countries, a significant part of which is imported into the Russian market.

One can also adduce a lot of facts and examples that hinder the development of the processing industry of the agroindustrial complex - a low solvency of the population due to low wages; a serious technological lag, which negatively affects the quality and competitiveness of products and creates the prerequisites for the inertial e development of the considered subcomplex of the AIC.

\section{Conclusions}

The imbalance of the economy ultimately leads to the fact that the main indicators of the standard of living (such as average per capita incomes, pensions, the subsistence minimum, etc.) are quite seriously behind the standards of economically advanced countries. The impossibly scanty income of the majority of the population does not allow forming the optimal demand in the segment of the agroindustrial production of high-tech and dietetic food products of the consumer market, which compels consumers to switch to a cheaper low-technology sector. Ultimately, all this hinders economic growth in various sectors of the processing sub-complex of the agroindustrial complex with all that it entails. Finally, it must be admitted that the manual regulation of social and economic policy, accompanied by private structural reforms, is not able to pacify the existing negative situation $[9,13]$.

- The identified deficiencies in the development of the processing sub-complex of the AIC made it possible to focus on measures of state support for agricultural and industrial production in the AIC, and also to offer a set of effective measures to develop the priority areas of the processing sub- 
complex of the AIC aimed at creating competitive advantages in the agroindustrial complex.

- The considered areas are at large universal and they can be used in the development of new programs and adjustment of existing ones for the implementation of state-targeted food security programs and the sustainable formation of competitive advantages in the AIC.

\section{Conflict of Interests}

The authors confirm the absence of a conflict of interest.

\section{References}

Abalkin L.I. Russia: Understanding the Fate and Fortunes: Monography. - M: Economic Nespaper, 2012. -863 p.

Aloeva Z.A., Misakov V.S. The Development of Adaptation and Anti-Crisis Measures Within the Context of Growing Competence //Izvestiya of the KabardinoBalkar Research Center of the RAS. - 2013. - № 6-2 (56). - P. 30-35.

Afashagova S.R., Misakov V.S., Ivanov A.A. Some Instruments of Stimulation of Innovation-Driven Growth in the Business Enviorenment in the Republics of the NCFD //Izvestiya of the Kabardino-Balkar Research Center of the RAS. - 2014. - № 5 (61). - P. 75-81.

Bespakhotny G.V. The Problem of Modernization of the AIC // Economy of Agricultural and Processing Companies of the AIC. - 2010, - №7. - P. 7-11

Bodrunov S.D. Reindustrialization of the Russian Economy: Imperatives, Potential, Risks // Economic Renovation of Russia. 2013. - №1. - P. 19-49

Vinnichek L.B. Methodology of Appraisal for Mechanism of Regulation of Agricultural Sector // International Farm Magazine. 2015. - №6. - P. 37-43

Golikov R.N. Evaluation of Agrarian Potentialas a Factor of Structuring Lands // Economics. - 2016. - №6. - P. 366-371

Davydov B. Organizational Context of Neoindustrial Development //Economist. 2012. - №6. - P. 43-48

Kondratiev N.D. The Problems of Economic Dynamics. - M.: Economy, 1989. - 526 p.

Kushbokova R.K., Shamurzaev Z.S., Misakov V.S. Some Approaches to the Management of Innovation Potential of Industrial Enterprises //Terra Economicus. 2009. - Vol. 7. - № 4-3. - P. 123-125.

Misakov A.V., Molamusov Z.K., Misakov V.S. Some Methods of Modelling Investment Activity of Industrial Enterprises in Uncertain Environment //Economics and Enterprise. - 2016. - № 1-2 (66). - P. 606610.

Mikhailushkin L.V. Modernization as a Chief Instrument of the AIC Development // Vestnik of AAE and P.- 2012. - №3. - P.
$41-49$

Uyanaev B.B. Misakov V.S. New Model of Development of Rural Regions and Ensuring Food Security of Russia / Izvestiya of the

Kabardino-Balkar Research Center of the RAS. - 2015. - № 3 (65). - C. 135-140.

Shardan S.K., Lainapov U.M. Peculiarities of Forming the AIC in a Region // The Territory of Economics. - Rostov on the Don: SFU. - 2010. - №2. - P. 420-426 